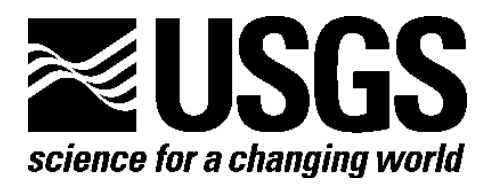

Prepared in cooperation with the Colorado River Basin Salinity Control Forum

\title{
Discharge, Water Quality, and Native Fish Abundance in the Virgin River, Utah, Nevada, and Arizona, in Support of Pah Tempe Springs Discharge Remediation Efforts
}

By Matthew P. Miller, Patrick M. Lambert, and Thomas B. Hardy

Open-File Report 2014-1104

U.S. Department of the Interior

U.S. Geological Survey 


\section{U.S. Department of the Interior \\ SALLY JEWELL, Secretary}

\section{U.S. Geological Survey \\ Suzette M. Kimball, Acting Director}

U.S. Geological Survey, Reston, Virginia: 2014

For more information on the USGS—-the Federal source for science about the Earth, its natural and living resources, natural hazards, and the environment-visit

http://www.usgs.gov or call 1-888-ASK-USGS

For an overview of USGS information products, including maps, imagery, and publications, visit http://www.usgs.gov/pubprod

To order this and other USGS information products, visit $h$ ttp://store.usgs.gov

Suggested citation:

Miller, M.P., Lambert, P.M., and Hardy, T.B., 2014, Discharge, water quality, and native fish abundance in the Virgin River, Utah, Nevada, and Arizona, in support of Pah Tempe Springs discharge remediation efforts: U.S. Geological Survey Open-File Report 2014-1104, 16 p., http://dx.doi.org/10.31133/ofr20141104

ISSN 2231-1258 (online)

Any use of trade, firm, or product names is for descriptive purposes only and does not imply endorsement by the U.S. Government.

Although this report is in the public domain, permission must be secured from the individual copyright owners to reproduce any copyrighted material contained within this report. 


\section{Contents}

Abstract

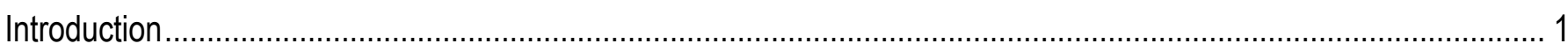

Purpose and Scope ………………………………… 2

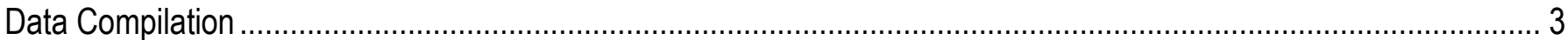

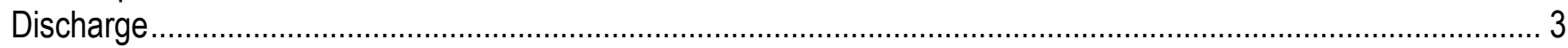

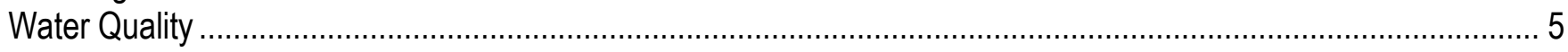

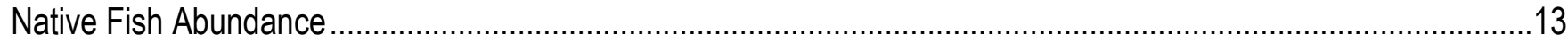

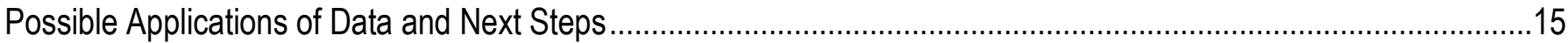

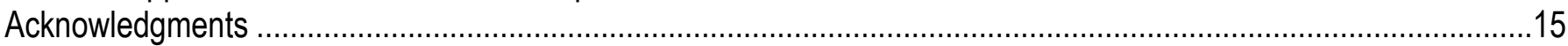

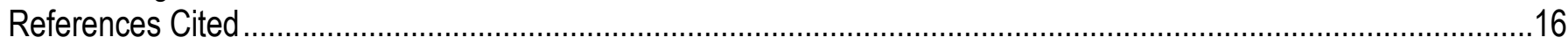

\section{Figures}

Figure 1. Time series plots of stream temperature, dissolved oxygen, and specific conductance measured at 15-minute intervals from 2007-2012 at the Virgin River at Virgin, UT, and Virgin River Above La Verkin Creek Near La Verkin, UT, streamgaging stations.

Figure 2. Native fish density data from the Virgin River Gage (VR104.72) and Virgin River Above Quail Creek (VR089.18) sites.

\section{Tables}

Table 1. Data availability summary and statistics for sites with continuously measured discharge along the Virgin River in Utah, Nevada, and Arizona......

Table 2. Data availability summary for sites with water-quality data along the Virgin River in Utah, Nevada, and

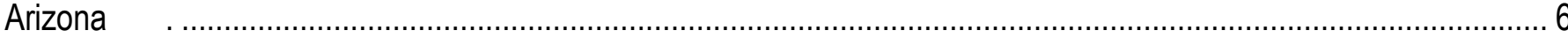

Table 3. Data availability summary for U.S. Geological Survey sites with continuous water-quality data along the Virgin River in Utah, Nevada, and Arizona.

Table 4. Data availability summary for Utah Department of Natural Resources and Utah State University sites with continuous temperature data.

\section{Appendixes}

\section{Appendixes 1-8 are available at http://pubs.usgs.gov/of/2014/1104/}

A1. Discharge data for 21 sites on the Virgin River (Microsoft .xlsx format)

A2. Water-quality data (Microsoft .xlsx format)

1. Water-quality data downloaded from the National Water Information System database

2. Water-quality data downloaded from the Water Quality Portal

A3. U.S. Geological Survey continuous water-quality data (Microsoft .xlsx format)

1. Continuous water-quality data for USGS station ID 09406000 Virgin River at Virgin, UT

2. Continuous water-quality data for USGS station ID 09406100 Virgin River Above La Verkin Creek Near La Verkin, UT

3. Continuous water-quality data for USGS station ID 09407810 Virgin River below Ash Creek Near La Verkin, UT 
4. Continuous water-quality data for USGS station ID 09408135 Virgin River Above Quail Creek Near Hurricane, UT

5. Continuous water-quality data for USGS station ID 09408150 Virgin River near Hurricane, UT

6. Continuous water-quality data for USGS station ID 09415000 Virgin River at Littlefield, AZ

7. Continuous water-quality data for USGS station ID 09415250 Virgin River Above Lake Mead near Overton, NV

A4. Utah Department of Natural Resources continuous temperature data (Microsoft .xlsx format)

A5. Utah State University continuous temperature data (Microsoft .xlsx format)

1. Continuous water temperature data collected in July 2005

2. Continuous water temperature data collected in September 2005

3. Continuous water temperature data collected in February 2007

4. Continuous water temperature data collected in May 2007

5. Continuous water temperature data collected in June 2007

A6. Virgin River fishes database (Microsoft .mbd format)

A7. Utah Department of Natural Resources full pass fish abundance data (Microsoft .xlsx format)

1. Combined young of year and adult abundance data

2. Young of year abundance data

3. Adult abundance data

A8. Utah Department of Natural Resources population response station fish abundance data (Microsoft .xlsx format) 


\section{Conversion Factors and Water-Quality Units}

\begin{tabular}{lcc}
\multicolumn{1}{c}{ Inch/Pound to SI } & \multicolumn{1}{c}{ By } & To obtain \\
\hline & Length & \\
\hline mile $(\mathrm{mi})$ & 1.609 & kilometer $(\mathrm{km})$ \\
\hline & Flow rate & \\
\hline cubic foot per second $\left(\mathrm{ft}^{3} / \mathrm{s}\right)$ & 0.02832 & cubic meter per second $\left(\mathrm{m}^{3} / \mathrm{s}\right)$ \\
\hline & Mass & \\
\hline ton per year (ton/yr) & 0.9072 & metric ton per year \\
\hline SI to Inch/Pound & & \\
\hline Multiply & By & \\
\hline & Area & \\
\hline square meter $\left(\mathrm{m}^{2}\right)$ & 10.76 & sobtain \\
\hline
\end{tabular}

Temperature in degrees Celsius $\left({ }^{\circ} \mathrm{C}\right)$ may be converted to degrees Fahrenheit $\left({ }^{\circ} \mathrm{F}\right)$ as follows:

${ }^{\circ} \mathrm{F}=\left(1.8 x^{\circ} \mathrm{C}\right)+32$

Temperature in degrees Fahrenheit $\left({ }^{\circ} \mathrm{F}\right)$ may be converted to degrees Celsius $\left({ }^{\circ} \mathrm{C}\right)$ as follows:

${ }^{\circ} \mathrm{C}=\left({ }^{\circ} \mathrm{F}-32\right) / 1.8$

Specific conductance is given in microsiemens per centimeter at 25 degrees Celsius $\left(\mu \mathrm{S} / \mathrm{cm}\right.$ at $\left.25^{\circ} \mathrm{C}\right)$.

Concentrations of chemical constituents in water are given either in milligrams per liter (mg/L) or micrograms per liter $(\mu \mathrm{g} / \mathrm{L})$. 


\title{
Discharge, Water Quality, and Native Fish Abundance in the Virgin River, Utah, Nevada, and Arizona, in Support of Pah Tempe Springs Discharge Remediation Efforts
}

\author{
By Matthew P. Miller, Patrick M. Lambert, and Thomas B. Hardy
}

\begin{abstract}
Pah Tempe Springs discharge hot, saline, low dissolved-oxygen water to the Virgin River in southwestern Utah, which is transported downstream to Lake Mead and the Colorado River. The dissolved salts in the Virgin River negatively influence the suitability of this water for downstream agricultural, municipal, and industrial use. Therefore, various remediation scenarios to remove the salt load discharged from Pah Tempe Springs to the Virgin River are being considered. One concern about this load removal is the potential to impact the ecology of the Virgin River. Specifically, information is needed regarding possible impacts of Pah Tempe Springs remediation scenarios on the abundance, distribution, and survival of native fish in the Virgin River. Future efforts that aim to quantitatively assess how various remediation scenarios to reduce the load of dissolved salts from Pah Tempe Springs into the Virgin River may influence the abundance, distribution, and survival of native fish will require data on discharge, water quality, and native fish abundance. This report contains organized accessible discharge, water quality, and native fish abundance data sets from the Virgin River, documents the compilation of these data, and discusses approaches for quantifying relations between abiotic physical and chemical conditions, and fish abundance.
\end{abstract}

\section{Introduction}

The Virgin River is home to six native fish species. Two of these species, the woundfin (Plagopterus argentissimus) and the Virgin River chub (Gila seminuda), are federally listed as endangered species. The Virgin spinedace (Lepidomeda mollispinis), while not federally listed, was proposed for listing as an endangered species in 1994. The other native fish species in the Virgin River include the speckled dace (Rhinichthys ocsulus), the desert sucker (Catostomus clarki), and the flannelmouth sucker (Catostomus latipinnis). The abundance and distribution of these fish in the Virgin River has been studied extensively. As with all organisms, the ability of the native fish of the Virgin River to survive in a given area is dependent on the physical, chemical, and biological conditions in the river. Specifically, each species can only survive in a specific range of habitat (e.g. discharge, temperature, dissolved solids, and dissolved oxygen) conditions.

Although many studies have quantified the abundance, distribution, and habitat requirements of native fish species in the Virgin River, the direct links between changing water quantity/quality conditions and native fish survival in the Virgin River are less clear. One source of water that influences 
the habitat conditions that the native fish species of the Virgin River depend on is Pah Tempe Springs, which discharge hot, saline, low dissolved-oxygen water to the Virgin River. Pah Tempe Springs discharge approximately 95,000 tons of dissolved solids annually to the Virgin River (Gerner, 2008) that are transported downstream and eventually discharged into the Colorado River. These dissolved salts negatively influence the suitability of this water for downstream agricultural, municipal, and industrial use. Recent studies by the U.S. Geological Survey (USGS) have estimated that removal of the dissolved solids discharged from Pah Tempe Springs would initially decrease the dissolved-solids load in the Virgin River at Littlefield, Arizona by 66,700 to 70,300 tons per year (tons/yr). In turn, the amount of salt moving into the Littlefield Springs system as a result of seepage from the Virgin River would be reduced, and the dissolved-solids load to the Virgin River at Littlefield, Arizona is predicted to decrease by an additional 20,600 to 24,200 tons/yr within 27 years (estimated lag time from river seepage) of mitigation (Gerner and Thiros, 2014).

On the basis of these estimated salinity load reductions, the Bureau of Reclamation Colorado River Basin Salinity Control Program (Program) has recommended assessing the feasibility and impacts of Pah Tempe Springs load removal, including the effects of mitigation on downstream Virgin River discharge, chemistry, and ecology. Specifically, managers would like to be able to answer the overarching question, "How will various remediation scenarios to reduce the load of dissolved solids from Pah Tempe Springs into the Virgin River influence the abundance, distribution, and survival of native fish?” The ability to quantitatively predict how future changes in water quantity and quality conditions in the Virgin River will influence native fish abundance, distribution, and survival would be an asset to Program managers charged with assessing the feasibility of mitigating the salinity load of Pah Tempe Springs and the effects of mitigation on the ecology of the Virgin River. A baseline set of discharge, water quality, and native fish abundance data are required to provide a foundation from which future models or assessments can be developed to quantitatively address the aforementioned overarching question.

\section{Purpose and Scope}

As a necessary first step towards quantifying the impacts of potential Pah Tempe Springs remediation scenarios on native fish, we have produced organized accessible discharge, water quality, and native fish data sets as eight separate appendixes. This report documents the compilation of data describing water quantity and quality characteristics that are anticipated to change in the Virgin River as a result of Pah Tempe Springs remediation scenarios, and that are known to influence native fish survival (i.e. discharge, temperature, dissolved oxygen, and total dissolved solids). Existing data on the abundance and distribution of native fish in the river are also documented. This work builds upon extensive work that has already been completed on native fish abundance and distribution, and (or) water-quality conditions as part of the Virgin River Resource Management and Recovery Program (http://www.virginriverprogram.org), and reported in publications by Utah State University (USU; Hardy and others, 2003), the Utah Department of Natural Resources (UTDNR; Fridell and Morvilius, 2005; Bennion and Fridell, 2006), and the U.S. Fish and Wildlife Service (USFWS; U.S. Fish and Wildlife Service, 1994). These previous water quality and (or) native fish studies in the Virgin River have not systematically compiled water quality and native fish abundance data that can be used to assess the impacts of Pah Tempe Springs remediation on native fish. This scope of work is unique in that it does systematically compile, and document the compilation of, fish abundance and distribution data using a pre-selected set of water-quality variables that are expected to change as a function of remediation and are known to influence native fish abundance, distribution, and survival. In addition to 
compiling, and documenting the compilation of, existing data, potential data analysis approaches that could be employed using the compiled data to quantitatively identify relations between chemical and physical conditions, and fish abundance and distribution in the Virgin River - a necessary step prior to quantifying the impacts of remediation scenarios on native fish - are discussed. Although this compilation does not include all discharge, water quality, or fish data previously collected for the Virgin River, it does provide an organized baseline set of data.

\section{Data Compilation}

\section{Discharge}

Discharge data were acquired from 21 sites on the Virgin River. Complete discharge records are presented in appendix 1, and the period of record for which data are available at these sites is summarized in table 1. Standard USGS methods were used to produce the discharge records (Rantz, 1982), and daily mean stream discharge data for each site were acquired from the USGS National Water Information System (NWIS) database (http://water.data.usgs.gov/nwis, accessed December, 2012). These 21 streamflow gaging stations are the only sites the USGS has operated, or currently operates on the Virgin River that provide a continuous record of discharge. Thirteen of the 21 sites currently (2012) have active streamflow gages. Point measurements of discharge not associated with a gaging station are not reported here. The average discharge record length is 30 years and varies from 273 days at the Virgin River Below Ash Creek Near LaVerkin, UT gage to 104 years at the Virgin River at Virgin, UT gage (table 1). Average daily mean discharge ranges from $5 \mathrm{ft}^{3} / \mathrm{s}$ at the North Fork Virgin River Near Glendale, UT gage to $342 \mathrm{ft}^{3} / \mathrm{s}$ at the Virgin River Above Halfway Wash Near Riverside, NV gage. 
Table 1. Data availability summary and statistics for sites with continuously measured discharge along the Virgin River in Utah, Nevada, and Arizona.

[USGS, U.S. Geological Survey; STAID, station ID; $\mathrm{ft}^{3} / \mathrm{s}$, cubic feet per second]

\begin{tabular}{|c|c|c|c|c|c|c|}
\hline USGS National Water Information System station name & $\begin{array}{l}\text { USGS } \\
\text { STAID }\end{array}$ & $\begin{array}{l}\text { Period of } \\
\text { record }\end{array}$ & $\begin{array}{c}\text { Average } \\
\text { discharge } \\
\left(\mathrm{ft}^{3} / \mathrm{s}\right)\end{array}$ & $\begin{array}{c}\text { Standard } \\
\text { deviation of } \\
\text { discharge }\left(\mathrm{ft}^{3} / \mathrm{s}\right)\end{array}$ & $\begin{array}{c}\text { Minimum } \\
\text { discharge } \\
\left(\mathrm{ft}^{3} / \mathrm{s}\right)\end{array}$ & $\begin{array}{l}\text { Maximum } \\
\text { discharge } \\
\left(\mathrm{ft}^{3} / \mathrm{s}\right)\end{array}$ \\
\hline East Fork Virgin River Near Glendale, UT & 9404450 & 1996-2012 & 18 & 20 & 3 & 624 \\
\hline East Fork Virgin River Near Mount Carmel Junction, UT & 9404700 & $1992-2002$ & 17 & 20 & 0 & 189 \\
\hline East Fork Virgin River Near Springdale, UT & 9404900 & $1991-2012$ & 57 & 50 & 26 & 2,120 \\
\hline North Fork Virgin River Near Glendale, UT & 9405400 & 1972-2012 & 5 & 5 & 0 & 39 \\
\hline North Fork Virgin River Below Bulloch Canyon Near Glendale, UT & 9405420 & 1974-1984 & 20 & 19 & 3 & 200 \\
\hline North Fork Virgin River Above Zion Narrows Near Glendale, UT & 9405450 & 1978-1984 & 26 & 24 & 2 & 200 \\
\hline North Fork Virgin River Above Big Bend Near Springdale, UT & 9405490 & 1991-1994 & 116 & 190 & 0 & 1,380 \\
\hline North Fork Virgin River Near Springdale, UT & 9405500 & 1923-2012 & 104 & 158 & 22 & 4,990 \\
\hline North Fork Virgin River Near Springdale, UT & 9405501 & 1968-1991 & 105 & 172 & 17 & 3,000 \\
\hline Virgin River at Virgin, UT & 9406000 & $1909-2012$ & 199 & 280 & 22 & 10,600 \\
\hline Virgin River Above La Verkin Creek Near La Verkin, UT & 9406100 & 2005-2012 & 109 & 246 & 16 & 7,900 \\
\hline Virgin River Below Ash Creek Near La Verkin, UT & 9407810 & 2004-2005 & 305 & 1,596 & 18 & 18,000 \\
\hline Virgin River Above Quail Creek Near Hurricane, UT & 9408135 & 1989-2012 & 201 & 497 & 20 & 13,500 \\
\hline Virgin River Near Hurricane, UT & 9408150 & $1967-2012$ & 213 & 383 & 22 & 13,700 \\
\hline Virgin River Near Bloomington, UT & 9413200 & $1977-2012$ & 221 & 460 & 5 & 17,800 \\
\hline Virgin River Near St. George, UT & 9413500 & $1950-2012$ & 190 & 438 & 0 & 18,000 \\
\hline Virgin River Above the Narrows Near Littlefield, AZ & 9413700 & 1998-2012 & 161 & 534 & 0 & 19,500 \\
\hline Virgin River at Littlefield, AZ & 9415000 & 1929-2012 & 242 & 495 & 40 & 25,000 \\
\hline Virgin River at Riverside, NV & 9415190 & 1970-1995 & 277 & 537 & 0 & 7,400 \\
\hline Virgin River Above Halfway Wash Near Riverside, NV & 9415230 & 1977-1985 & 342 & 476 & 0 & 7,580 \\
\hline Virgin River Above Lake Mead Near Overton, NV & 9415250 & 2006-2012 & 159 & 362 & 0 & 13,900 \\
\hline
\end{tabular}




\section{Water Quality}

Water-quality data were acquired from 87 sites on the Virgin River upstream of Lake Mead. Complete water-quality data sets are presented in appendix 2, and the period of record and number of samples collected at each site are summarized in table 2 . Water-quality data compiled here are limited to constituents that are expected to change in response to remediation of Pah Tempe Springs and that are known to influence native fish abundance, distribution, and survival. These constituents include stream temperature, dissolved-oxygen concentration, and dissolved-solids concentration. Water-quality data were generated from samples collected by the following six agencies: the Arizona Department of Environmental Quality (AZDEQ), the Utah Department of Environmental Quality (UTDEQ), USU, the U.S. Environmental Protection Agency (EPA), the National Park Service (NPS), and the USGS. Discrete water-quality data generated from samples collected by the USGS were acquired from the NWIS database (accessed December 2012 at http://nwis.waterdata.usgs.gov/nwis), and data generated from samples collected by the AZDEQ, UTDEQ, EPA, and the NPS were acquired from the Water Quality Portal (WQP, http://www.waterqualitydata.us/, accessed December 2012). Water samples collected by the USGS were collected using standard USGS methods (U.S. Geological Survey, variously dated), and were analyzed at the USGS National Water Quality Laboratory (NWQL), in Denver, Colorado. Water samples collected by non-USGS entities were collected and analyzed according to organization-specific protocols. The average water-quality record length is 9.5 years, and varies from 1 day at a number of sites to 63 years at the Virgin River at Littlefield, AZ site (table 2). Forty eight of the 87 sites have fewer than 10 data points for each water-quality constituent, and only 5 sites have more than 100 data points for each water-quality constituent. The site with the most waterquality data is the same site that has the longest water-quality period of record, the Virgin River at Littlefield, AZ.

Of the 54 water-quality sites sampled by the USGS, continuous measurements of stream temperature, dissolved oxygen, and specific conductance (a proxy for dissolved-solids concentration) are available for 7 sites. Complete continuous water-quality data sets are presented in appendix 3, and the period of record for which data are available at these sites is summarized in table 3 . Two of these sites, the Virgin River at Virgin, UT, and the Virgin River Above La Verkin Creek Near La Verkin, UT, have continuous data collected at 15-minute intervals through present (2014) day (table 3, fig. 1). Data for the other five sites are reported at a daily time step, and only historical data are available for these sites.

In addition to the continuous USGS water-quality data, the UTDNR and USU have collected continuous instream temperature data. Continuous temperature data were collected by the UTDNR at 17 sites on the mainstem of the Virgin River for different periods of record at each site (appendix 4, table 4). Data collected from 2001 to 2005 were collected at 15-minute, 30-minute or 1-hour intervals, whereas data collected after 2005 were collected at 10-minute intervals. Continuous temperature data were collected by USU at 5-minute intervals at four sites on the mainstem of the Virgin River for multiple days during five distinct time periods (appendix 5, table 4). 
Table 2. Data availability summary for sites with water-quality data along the Virgin River in Utah, Nevada, and Arizona.

[USGS, U.S. Geological Survey; NWIS, National Water Information System; STAID, station ID; DO, dissolved oxygen; TDS, total dissolved solids; ROE, residue on evaporation at 180 degrees Celsius; SC, sum of constituents; WQP, Water Quality Portal]

\begin{tabular}{|c|c|c|c|c|c|c|}
\hline \multicolumn{7}{|c|}{ NWIS Data } \\
\hline USGS NWIS station name & USGS STAID & Period of record & $\begin{array}{l}\text { Number of } \\
\text { temperature } \\
\text { data points }\end{array}$ & $\begin{array}{l}\text { Number of DO } \\
\text { data points }\end{array}$ & $\begin{array}{l}\text { Number of } \\
\text { TDS (ROE) } \\
\text { data points }\end{array}$ & $\begin{array}{c}\text { Number of } \\
\text { TDS (SC) } \\
\text { data points }\end{array}$ \\
\hline East Fork Virgin River Near Glendale, UT & 9404450 & 1966-2012 & 196 & 4 & 1 & 119 \\
\hline East Fork Virgin River Near Springdale, UT & 9404900 & 2008-2012 & 28 & 0 & 0 & 18 \\
\hline Nf Virgin River Near Glendale, UT & 9405400 & 1973-1978 & 38 & 0 & 0 & 37 \\
\hline N Fk Virgin R Blw Bulloch Canyon Nr Glendale & 9405420 & 1974-1986 & 69 & 2 & 0 & 64 \\
\hline N Fk Virgin R Abv Zion Narrows Nr Glendale & 9405450 & 1979-1986 & 54 & 4 & 3 & 24 \\
\hline North Fork Virgin River Near Springdale, UT & 9405500 & 1983-2012 & 55 & 0 & 0 & 6 \\
\hline North Fork Virgin River Nr Springdale, UT & 9405501 & 1973-1991 & 63 & 2 & 0 & 2 \\
\hline Virgin River At Virgin, UT & 9406000 & 1962-2012 & 328 & 77 & 9 & 125 \\
\hline Virgin River Ab La Verkin Creek Nr La Verkin, UT & 9406100 & 2009-2012 & 83 & 78 & 5 & 76 \\
\hline Virgin River Ab Quail Creek Near Hurricane, UT & 9408135 & 1989-2012 & 46 & 0 & 6 & 44 \\
\hline Virgin River Near Hurricane, UT & 9408150 & $1967-2012$ & 294 & 4 & 7 & 204 \\
\hline Virgin River Near Bloomington, UT & 9413200 & 1977-2012 & 147 & 4 & 4 & 18 \\
\hline Virgin R At Bloomington, UT & 9413300 & 1978-1979 & 16 & 13 & 16 & 0 \\
\hline Virgin River Near St. George, UT & 9413500 & $1966-2013$ & 59 & 9 & 14 & 0 \\
\hline Virgin R. Abv I15 Rest Area Nr Littlefield, AZ & 9413600 & 1977-1979 & 18 & 17 & 18 & 0 \\
\hline Virgin R. Blw I15 Rest Area Nr Littlefield, AZ & 9413650 & $1977-2010$ & 19 & 19 & 18 & 0 \\
\hline Virgin Rv Abv The Narrows Nr Littlefield, AZ & 9413700 & 1998-2011 & 68 & 59 & 0 & 0 \\
\hline Virgin R At Mouth Of Narrows Nr Littlefield, AZ & 9413800 & $1977-1979$ & 26 & 23 & 26 & 2 \\
\hline Virgin Rv At Littlefield, AZ & 9415000 & $1949-2012$ & 563 & 255 & 680 & 31 \\
\hline Virgin Rv At Mesquite, NV & 9415090 & 1992-1992 & 2 & 2 & 0 & 0 \\
\hline
\end{tabular}




\begin{tabular}{|c|c|c|c|c|c|c|}
\hline Virgin Rv At Riverside, NV & 9415190 & 1974-1995 & 23 & 2 & 0 & 2 \\
\hline Virgin Rv Blw Riverside, NV & 9415200 & $1969-1974$ & 28 & 23 & 24 & 15 \\
\hline Virgin Rv Abv Halfway Wash Nr Riverside, NV & 9415230 & 1978-1995 & 94 & 59 & 61 & 56 \\
\hline Virgin Rv Abv Lake Mead Nr Overton, NV & 9415250 & 2008-2012 & 11 & 6 & 8 & 0 \\
\hline Virgin River Abv Beaver Dam Wash, AZ & 365006113585301 & 1981-1982 & 4 & 4 & 0 & 3 \\
\hline Virgin River At Desert Springs & 365440113534001 & 2012 & 0 & 0 & 1 & 1 \\
\hline Virgin River Blw Virgin River Gorge Springs, AZ & 365508113513301 & 1981-1982 & 2 & 2 & 0 & 2 \\
\hline (B-41-14)21cba Virgin R. Blw Sullivan Canyon & 365614113492701 & 2010 & 1 & 0 & 0 & 1 \\
\hline (B-41-14)21ada Virgin R. Abv Sullivan Canyon & 365625113484801 & 2010 & 1 & 0 & 0 & 1 \\
\hline (B-41-14)14ccc Virgin R. At I-15 Rest Area & 365648113472401 & 2010 & 1 & 0 & 0 & 0 \\
\hline Virgin River At Black Rock Gulch, Nr St. George, UT & 365812113434101 & 2009-2010 & 2 & 0 & 2 & 1 \\
\hline Virgin River Below Confluence, UT & 370842113020601 & 1981-1982 & 4 & 4 & 0 & 3 \\
\hline East Fork Virgin River Above Confluence, UT & 370947113003801 & 1981-1982 & 4 & 4 & 0 & 4 \\
\hline North Fork Virgin River Above Confluence, UT & 370948113004401 & 1981-1982 & 4 & 4 & 0 & 2 \\
\hline Virgin River Above Leeds Creek, UT & 371042113223501 & 1981-1982 & 5 & 5 & 0 & 3 \\
\hline Virgin River Lower Sect & 371100113211501 & 1975 & 1 & 0 & 0 & 0 \\
\hline Virgin River Below La Verkin Hot Springs, UT & 371122113162201 & $1981-2010$ & 11 & 4 & 7 & 0 \\
\hline Virgin River Above La Verkin Hot Springs, UT & 371127113155901 & $1981-2010$ & 10 & 4 & 6 & 0 \\
\hline Virgin River Upper Sect & 371155113180501 & 1975 & 1 & 0 & 0 & 0 \\
\hline Virgin River Above North Creek, UT & 371204113103501 & 1981-1982 & 4 & 4 & 0 & 0 \\
\hline Virgin River Below Ash Creek, UT & 371208113172501 & 1981-1982 & 5 & 5 & 0 & 0 \\
\hline Nf Virgin River Nr Springdale Qw & 371235112584002 & 1973-1980 & 23 & 0 & 0 & 0 \\
\hline E. Fk. Virgin R. At Mt. Carmel Junction, UT & 371247112410801 & 1981-1982 & 4 & 4 & 0 & 0 \\
\hline North Fork Virgin River At Mouth Of Narrows, UT & 371705112565001 & 1981-1987 & 6 & 4 & 0 & 0 \\
\hline North Fork Virgin River At Big Spring & 371952112572101 & 1986 & 1 & 0 & 0 & 0 \\
\hline East Fk Virgin River Abv Lydias Canyon, UT & 372028112361201 & 1982 & 1 & 1 & 0 & 0 \\
\hline N Fk Virgin River At Confluence With Deep Creek & 372134112570301 & 1986 & 1 & 0 & 0 & 0 \\
\hline
\end{tabular}


N. F. Virgin River Past

North Fork Virgin River Above Deep Creek

E. Fk. Virgin R. Above Stout Canyon, UT

No. Fork Virgin River Near Pond

N Fk Virgin R Nr Willow Canyon

E. Fk. Virgin R. At Highway 136 Bridge, UT

N Fk Virgin R Blw Rosy Canyon

\begin{tabular}{rr}
372218112521001 & 1987 \\
372218112523301 & 1986 \\
372237112352501 & $1981-1982$ \\
372247112504601 & 1987 \\
372405112483301 & 1986 \\
372538112320701 & $1981-1982$ \\
372642112470401 & 1986 \\
\hline
\end{tabular}

WQP Data

\begin{tabular}{|c|c|c|c|c|c|}
\hline \\
\hline Monitoring location name & Monitoring location identifier & $\begin{array}{l}\text { Period of } \\
\text { record }\end{array}$ & $\begin{array}{c}\text { Number of } \\
\text { temperature } \\
\text { data points }\end{array}$ & $\begin{array}{c}\text { Number of } \\
\text { DO data } \\
\text { points }\end{array}$ & $\begin{array}{c}\text { Number of } \\
\text { TDS data } \\
\text { points } \\
\end{array}$ \\
\hline N Fork Virgin R Above Confluence With E Fork & 11NPSWRD-ZION_EPA_NFVR1 & 1976 & 3 & 3 & 0 \\
\hline E Fork Virgin R Above Confluence With N Fork & 11NPSWRD-ZION_EPA_VR5 & 1976 & 2 & 2 & 0 \\
\hline Virgin River Near Virgin UT & 11NPSWRD-ZION_EPA_VR7 & 1976 & 2 & 2 & 0 \\
\hline Virgin River Near La Verkin Hot Springs & 11NPSWRD-ZION_EPA_VR8 & 1976 & 3 & 3 & 0 \\
\hline Virgin River & 11NPSWRD-ZION_NF_VR & 1987 & 1 & 0 & 0 \\
\hline East Fork Virgin River Below Parunuweap Canyon & 11NPSWRD-ZION_NPSWRD_157 & 1992 & 11 & 9 & 0 \\
\hline Virgin River At Virgin UT & 11NPSWRD-ZION_UTDNR_32 & 1981-1982 & 5 & 5 & 0 \\
\hline Virgin River Above North Creek & 11NPSWRD-ZION_UTDNR_33.1 & 1981-1982 & 5 & 5 & 0 \\
\hline Virgin River Below Confluence & 11NPSWRD-ZION_UTDNR_38 & 1981-1982 & 5 & 5 & 0 \\
\hline North Fork Of The Virgin River Above Confluence & 11NPSWRD-ZION_UTDNR_39 & 1981-1982 & 5 & 5 & 0 \\
\hline North Fork Of The Virgin River Near Springdale & 11NPSWRD-ZION_UTDNR_40 & 1981-1982 & 4 & 4 & 0 \\
\hline East Fork Virgin River Above Confluence & 11NPSWRD-ZION_UTDNR_56 & 1981-1982 & 5 & 5 & 0 \\
\hline Virgin River - At Littlefield, AZ & 21ARIZ_WQX-CGVGR039.41 & $2009-2010$ & 4 & 2 & 10 \\
\hline Virgin River - Below The Narrows & 21ARIZ_WQX-CGVGR043.36 & 2010 & 1 & 1 & 3 \\
\hline Virgin River - At I-15 Rest Stop & 21ARIZ_WQX-CGVGR052.23 & $2009-2010$ & 4 & 2 & 10 \\
\hline Virgin River & NARS-WAZP99-0712 & 2002 & 1 & 1 & 0 \\
\hline Virgin R At Utah-Ariz Stateline & UTAHDWQ_WQX-4950010 & 1976-1983 & 5 & 4 & 4 \\
\hline
\end{tabular}




\begin{tabular}{|c|c|c|c|c|c|}
\hline Virgin R Bl First Narrows \& New St George WWTP & UTAHDWQ_WQX-4950020 & 1984-2209 & 147 & 149 & 155 \\
\hline Virgin R At Bloomington Xing Ab St George WWTP & UTAHDWQ_WQX-4950120 & $1977-2009$ & 73 & 73 & 28 \\
\hline Virgin R Ab Santa Clara R \& Bl Old St George WWTP & UTAHDWQ_WQX-4950130 & 1976-1999 & 20 & 11 & 14 \\
\hline Virgin River At I-15 Virgin R Gorge Rest Area (AZ) & UTAHDWQ_WQX-4950160 & 1991 & 2 & 2 & 2 \\
\hline Virgin R Se Of St George @ Cr Xing & UTAHDWQ_WQX-4950200 & $1975-2006$ & 96 & 75 & 75 \\
\hline Virgin R Ab Washington Lagoons & UTAHDWQ_WQX-4950260 & $1982-1983$ & 6 & 4 & 0 \\
\hline Virgin R Bl Hot Springs & UTAHDWQ_WQX-4950300 & $2000-2002$ & 2 & 2 & 0 \\
\hline Virgin R At U15 Xing W Of Hurricane & UTAHDWQ_WQX-4950320 & $1976-2006$ & 134 & 126 & 126 \\
\hline Virgin R At U17 Xing N Of Hurricane (E Of Laverkin) & UTAHDWQ_WQX-4950810 & $1980-1985$ & 11 & 11 & 8 \\
\hline Virgin R 1 Mi E Of Virgin & UTAHDWQ_WQX-4950850 & $1982-2006$ & 89 & 84 & 90 \\
\hline Virgin R At Cr Xing In Rockville & UTAHDWQ_WQX-4950900 & $1976-1982$ & 14 & 14 & 12 \\
\hline N Fk Virgin R Ab Cnfl / E Fk Virgin R & UTAHDWQ_WQX-4950950 & $1979-2006$ & 167 & 164 & 165 \\
\hline N Fk Virgin R Bl Zion Natl Park WWTP Outfall & UTAHDWQ_WQX-4951100 & $1976-1984$ & 5 & 1 & 1 \\
\hline N Fk Virgin R Ab Zion Natl Park WWTP Outfall & UTAHDWQ_WQX-4951130 & $1975-1976$ & 5 & 0 & 5 \\
\hline N Fk Virgin R @ Hwy 9 Xing In Zion NP & UTAHDWQ_WQX-4951195 & 2006 & 3 & 3 & 3 \\
\hline E Fk Virgin R Ab Cnfl / N Fk Virgin R & UTAHDWQ_WQX-4951400 & 1982-2009 & 157 & 155 & 157 \\
\hline
\end{tabular}



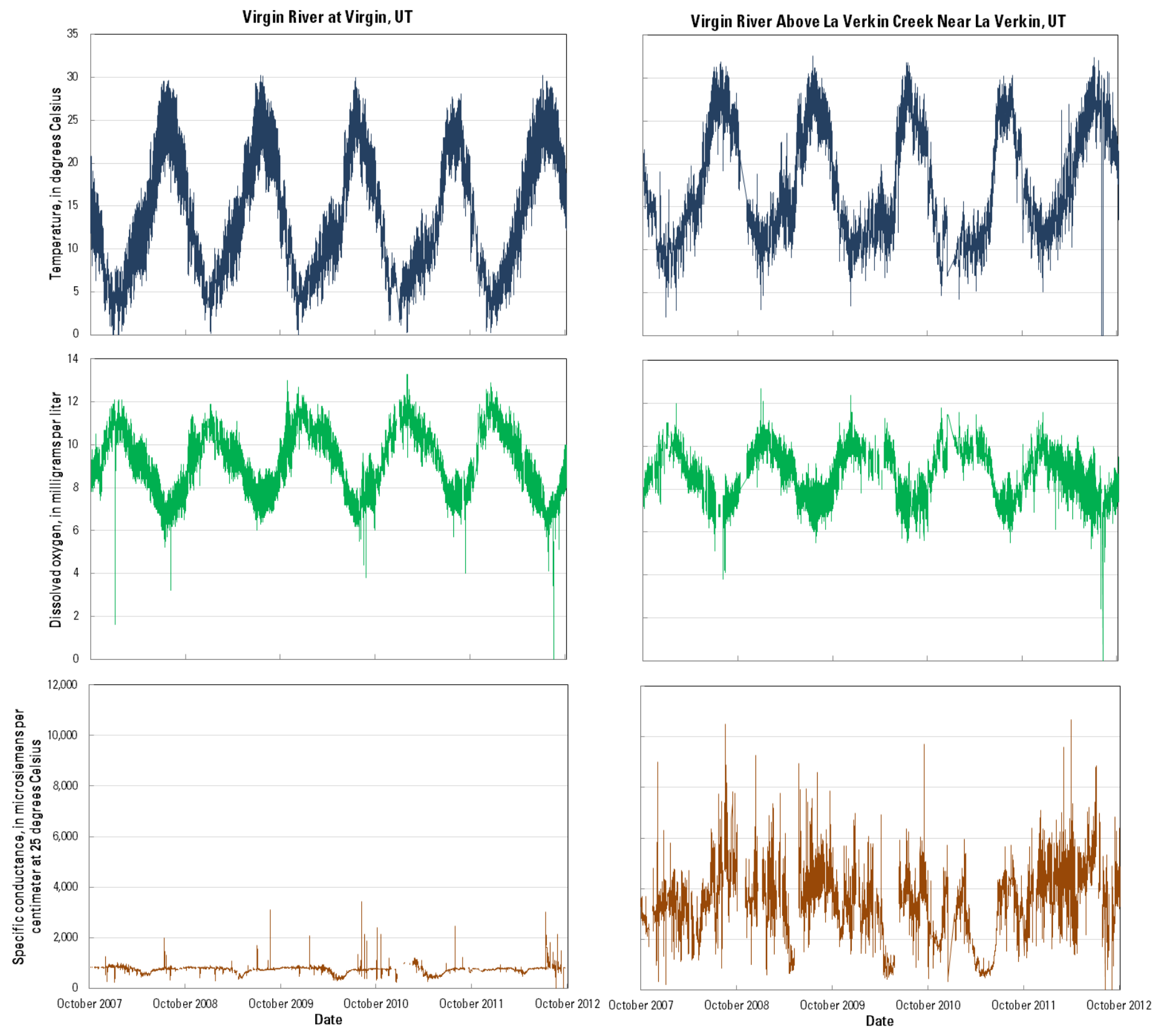

Figure 1. Time series plots of stream temperature, dissolved oxygen, and specific conductance measured at 15-minute intervals from 2007-2012 at the Virgin River at Virgin, UT, and Virgin River Above La Verkin Creek Near La Verkin, UT, streamgaging stations. The Virgin River at Virgin, UT, gage is located directly upstream of where Pah Tempe Springs discharge to the Virgin River, and the Virgin River Above La Verkin Creek Near La Verkin, UT, gage is located directly downstream of the Pah Tempe Springs confluence. 
Table 3. Data availability summary for U.S. Geological Survey sites with continuous water-quality data along the Virgin River in Utah, Nevada, and Arizona.

[USGS, U.S. Geological Survey; STAID, station ID; ND, no data]

\begin{tabular}{|c|c|c|c|c|c|}
\hline Station name & $\begin{array}{l}\text { USGS } \\
\text { STAID }\end{array}$ & $\begin{array}{c}\text { Stream } \\
\text { temperature }\end{array}$ & Dissolved oxygen & Specific conductance & $\begin{array}{c}\text { Reporting } \\
\text { interval }\end{array}$ \\
\hline Virgin River at Virgin, UT & 9406000 & 2007-2012 & 2007-2012 & 2007-2012 & 15 minutes \\
\hline Virgin River Above La Verkin Creek Near La Verkin, UT & 9406100 & 2007-2012 & 2007-2012 & 2007-2012 & 15 minutes \\
\hline Virgin River Below Ash Creek Near La Verkin, UT & 9407810 & 2004-2005 & 2004-2008 & 2004-2008 & Daily \\
\hline Virgin River Above Quail Creek Near Hurricane, UT & 9408135 & 1992-1993 & ND & ND & Daily \\
\hline Virgin River Near Hurricane, UT & 9408150 & 1967-1993 & ND & ND & Daily \\
\hline Virgin River at Littlefield, AZ & 9415000 & 1947-1988 & ND & 1949-1988 & Daily \\
\hline Virgin River Above Lake Mead Near Overton, NV & 9415250 & 2008-2010 & 2009-2010 & 2008-2010 & Daily \\
\hline
\end{tabular}


Table 4. Data availability summary for Utah Department of Natural Resources (UTDNR) and Utah State University (USU) sites with continuous temperature data.

\begin{tabular}{|c|c|c|c|}
\hline \multicolumn{4}{|c|}{ UTDNR Data } \\
\hline Station Name & Latitude & Longitude & Period of record \\
\hline Sheep Bridge & 37.199523 & -113.212385 & 2001-2012 \\
\hline Above Quail Creek Diversion & 37.199512 & -113.234083 & 2004-2012 \\
\hline Below Quail Creek Diversion & 37.196936 & -113.240181 & 2004-2012 \\
\hline Below Pah Tempe & 37.190546 & -113.276625 & 2001-2012 \\
\hline Below LaVerkin Hydroplant & 37.190904 & -113.279553 & 2004-2012 \\
\hline Above LaVerkin Creek & 37.197309 & -113.285289 & 2001-2012 \\
\hline Below Ash Creek & 37.200954 & -113.291122 & 2001-2012 \\
\hline Above Gould's Wash & 37.194834 & -113.333193 & 2004-2012 \\
\hline Above Quail Creek Near Stratton Pond & 37.180386 & -113.372732 & 2001-2012 \\
\hline At Hurricane Bridge (SR9) & 37.162705 & -113.395094 & 2001-2012 \\
\hline Above Washington Fields Diversion & 37.128624 & -113.422450 & 2001-2012 \\
\hline Below Washington Fields Diversion & 37.117062 & -113.439985 & 2010-2012 \\
\hline Below Palmer Ranch & 37.117848 & -113.465117 & $2005-2012$ \\
\hline Twin Bridges Population Response Station & 37.087092 & -113.550253 & 2010 \\
\hline Bloomington USGS Gage & 37.070779 & -113.581544 & 2005-2012 \\
\hline Man O’ War Population Response Station & 37.041641 & -113.601872 & 2010-2012 \\
\hline Below Stateline Barrier & 37.014810 & -113.681295 & 2004-2012 \\
\hline \multicolumn{4}{|c|}{ USU Data } \\
\hline Station Name & Latitude & Longitude & Periods of record \\
\hline Below Gould's Wash & 37.199994 & -113.342328 & $\begin{array}{r}7 / 19 / 2005-7 / 21 / 2005 \\
9 / 28 / 2005-10 / 1 / 2005 \\
2 / 6 / 2007-2 / 9 / 2007 \\
5 / 6 / 2007-5 / 16 / 2007 \\
6 / 20 / 2007-7 / 2 / 2007\end{array}$ \\
\hline Above Stratton Pond & 37.181653 & -113.373039 & $\begin{array}{r}5 / 6 / 2007-5 / 16 / 2007 \\
6 / 21 / 2007-6 / 25 / 2007\end{array}$ \\
\hline Hurricane Bridge & 37.161686 & -113.396717 & $\begin{array}{r}7 / 18 / 2005-7 / 21 / 2005 \\
9 / 28 / 2005-10 / 1 / 2005 \\
2 / 6 / 2007-2 / 9 / 2007 \\
5 / 6 / 2007-5 / 16 / 2007 \\
6 / 21 / 2007-6 / 25 / 2007\end{array}$ \\
\hline Above Washington Fields Diversion & 37.119289 & -113.430272 & $\begin{array}{r}7 / 19 / 2005-7 / 21 / 2005 \\
9 / 28 / 2005-10 / 1 / 2005 \\
2 / 6 / 2007-2 / 9 / 2007 \\
5 / 6 / 2007-5 / 16 / 2007 \\
6 / 20 / 2007-6 / 28 / 2007 \\
\end{array}$ \\
\hline
\end{tabular}




\section{Native Fish Abundance}

Native fish abundance data were acquired from the Virgin River fishes database and from data sets generated by the UTDNR. The Virgin River fishes database contains long-term monitoring data on native fish in the Virgin River and major tributaries, and is included as appendix 6. The database contains data collected in the mainstem of the Virgin River from 1976 to 2005. The database has built-in "forms" that allow the user to run queries for selected conditions. The "Report Form-Master" data form allows the user to select fish abundance data by site and date range. Using the "Station Name Lookup" pull-down menu, the user can select a site. Following site selection, the "ID Lookup" field will be populated with the Site ID. The Site ID indicates the water body and location, in upstream river miles. For example, the "Above LaVerkin Creek" site has a corresponding Site ID of "VR095.96”, which indicates that the site is on the Virgin River 95.96 miles upstream from Lake Mead. Once the user has identified the site(s) from which they would like to acquire data, a spatial range using the "Downstream site" and "Upstream site" data fields can be defined. A temporal range also can be defined using the "Begin" and "End” Date/Hour/Min data fields. A variety of data output formats are available, including data by individual seining units, data combining seining units by date, and data combined by species, station, or station/date.

Fish density data from the Virgin River Gage (site ID: VR104.72) and Virgin River Above Quail Creek (site ID: VR089.18) sites are shown in figure 2 as examples of the types of data available in the database. These sites roughly correspond to the Virgin River at Virgin, UT (USGS STAID: 9406000) and the Virgin River Above Quail Creek Near Hurricane, UT (USGS STAID: 9408135) gaging stations respectively, which have been sampled for water quality by the USGS (tables 1, 2, and 3).

The UTDNR has a number of ongoing fish monitoring efforts. Data sets from two of those efforts (full pass and population response stations) are included here. The full pass sampling is a more intensive sampling effort that occurs less regularly, as compared with the population response stations sampling, which is a less intensive sampling effort that occurs on a regular basis. The full pass data set contains information on native and non-native fish abundance in six reaches of the mainstem of the Virgin River from below Pah Tempe Springs to the Washington Fields Diversion (appendix 7). The full pass data set was generated by systematically seining all available habitats within each of the six reaches (see appendix 7 for reach definitions) two to three times per year from 2002 to 2012. Fish were enumerated into two age/size classes (young of year and adult), with the exception of fish sampled during the first two samplings of 2002. The methodology and results from each year of full pass sampling are detailed in yearly reports generated by the UTDNR (e.g. for 2004 sampling see Fridell and Morvilius, 2005; similar reports are available for all other sample years). The UTDNR population response stations data set contains information on native fish abundance in seven 1.5-mi reaches of the mainstem of the Virgin River (appendix 8). The Quail Creek station was split into two 0.75-mi reaches (Above Quail Creek and Below Quail Creek). Fifty seine hauls were conducted monthly from MarchOctober and twice in the winter months from 2003 to 2012 in each reach in proportion to available habitat in the reach. Fish were measured, separated into two size classes (young of year and adult) and enumerated. The methodology and results from each year of population response station sampling are detailed in yearly reports generated by the UTDNR (e.g. for 2005 sampling see Bennion and Fridell, 2006; similar reports are available for all other sample years). 

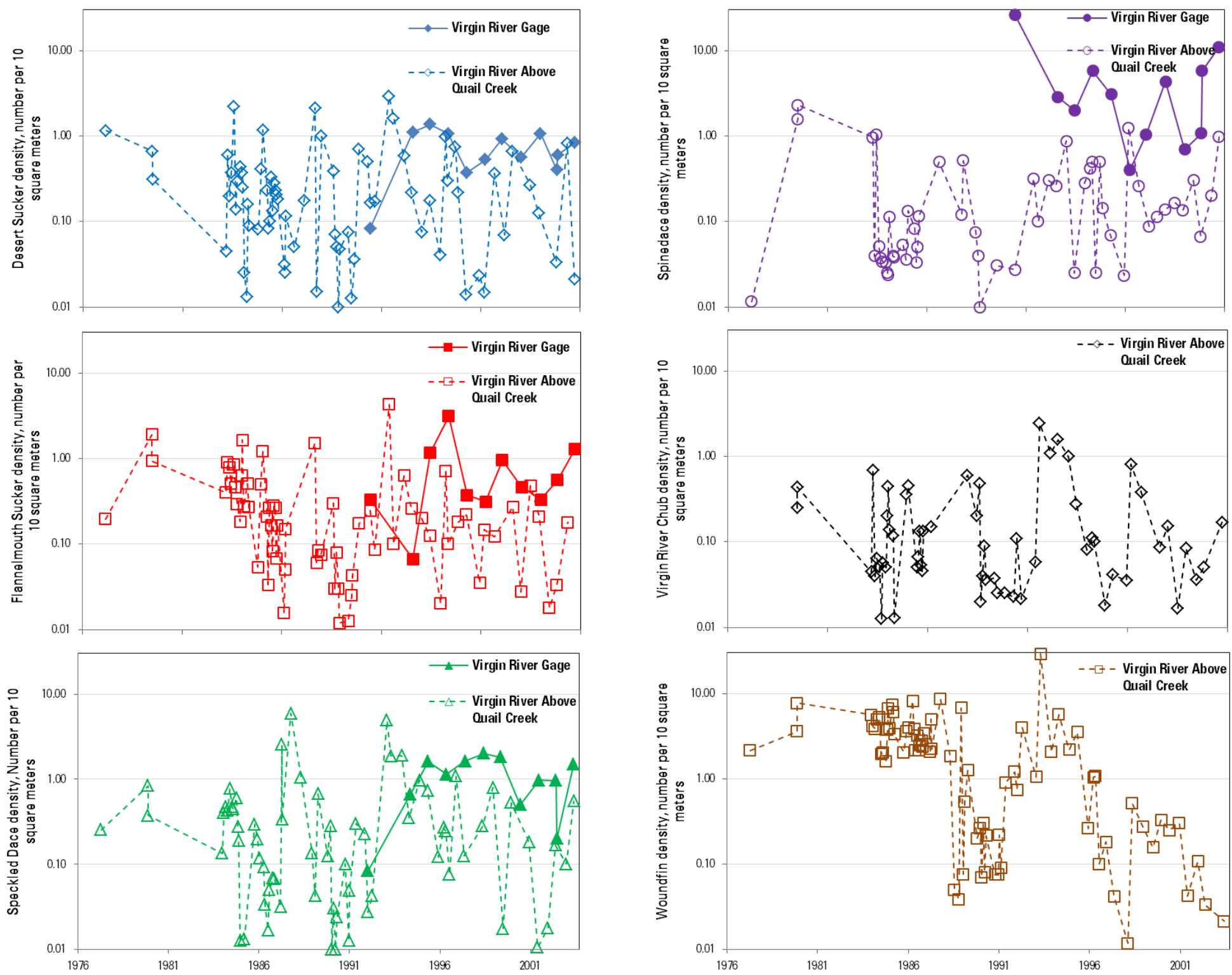

Figure 2. Native fish density data from the Virgin River Gage (VR104.72) and Virgin River Above Quail Creek (VR089.18) sites. Neither Virgin River chub nor woundfin were found during sampling at the Virgin River Gage site. The Virgin River Gage site is located upstream of where Pah Tempe Springs discharge to the Virgin River, and the Virgin River Above Quail Creek site is located downstream of the Pah Tempe Springs confluence. 


\section{Possible applications of data and next steps}

There are two requirements that need to be met to answer the overarching question, "How will various remediation scenarios to reduce the load of dissolved solids from Pah Tempe Springs into the Virgin River influence the abundance, distribution, and survival of native fish?” The first of these requirements is a foundational understanding of the relations between discharge, water quality, and fish abundance. The second is that adequate data are available to model the effects of abiotic drivers on native fish abundance, distribution, and survival. We discuss an approach by which the data compiled here could be used to directly address the first requirement, that is, developing a quantitative understanding of the relations between abiotic physical and chemical conditions, and native fish abundance and distribution in the Virgin River. Such an understanding will provide insight into the adequacy of available data for model development. Final determination of the adequacy of the data compiled here for the purpose of modeling the effects of abiotic drivers on native fish (the second requirement) is beyond the scope of this report, and will be dependent upon the constituents being modeled and the specific modeling approaches that are used.

Data sources required to meet the first requirement would include all of the discharge, water quality, and fish data compiled in this report. Measured discharge and water-quality conditions as well as statistics (i.e. average, standard deviation, minimum, maximum, concentration/discharge) could be assessed as drivers of change in fish community composition. A non-metric multidimensional (NMDS) ordination plot could be generated to identify spatial and temporal patterns in fish community composition. Subsequently, correlations between the fish community and all possible subsets of discharge and water-quality conditions/statistics could be assessed by using BIOENV (Clarke and Ainsworth, 1993). The use of NMDS and BIOENV to quantify relations between aquatic biota and abiotic environmental conditions has been applied successfully in other southwestern streams and rivers (Miller and Brasher, 2011). This proposed approach would identify drivers (i.e. discharge, temperature, dissolved solids, and dissolved oxygen) of change in fish abundance across space and time, and build upon analyses investigating changes in fish abundance in response to changes in discharge and temperature using some of the population response station fish data collected by UTDNR staff (Meribeth Huizinga, oral commun., 2013). This approach would also identify potential data gaps that could inform future sampling/monitoring efforts to, in part, provide data needed for modeling abioticbiotic relations. Coupling abiotic-biotic relations identified in this way with future predictions of how water quality and discharge may change in response to various Pah Tempe Springs remediation scenarios would provide the foundational information needed to develop assessment methods and models capable of predicting the abundance, distribution, and survival of native fish in response to remediation efforts.

\section{Acknowledgments}

We are grateful to the numerous employees who collected the samples and data compiled in this study. Adriana Garcia assisted with water-quality data compilation, Melinda Bennion and Marin Schijf provided UTDNR fish and temperature data, and Bethany Neilson provided USU temperature data. Anne Brasher and Bethany Neilson commented on an earlier version of this manuscript. 


\section{References Cited}

Bennion, M.R.M., and Fridell, R.A., 2006, Virgin River fish population response station summary 2005: Utah Division of Wildlife Resources Publication 06-11, 166 p.

Clarke, K.R., and Ainsworth, M., 1993, A method of linking multivariate community structure to environmental variables: Marine Ecology Progress Series, v. 92, p. 205-219.

Fridell, R.A., and Morvilius, M.K., 2005, Distribution and abundance of fish in the Virgin River between the Washington Fields Diversion and Pah Tempe, 2004: Utah Division of Wildlife Resources Publication 05-21, 38 p.

Gerner, S.J., 2008, Dissolved-solids sources and transport in the Virgin River Basin in Utah, Arizona, and Nevada with emphasis on dissolved solids discharged from Pah Tempe Springs: U.S. Geological Survey Administrative Report, 26 p.

Gerner, S.J., and Thiros, S.A., eds., 2014, Hydrosalinity studies of the Virgin River, Dixie Hot Springs, and Littlefield Springs, Utah and Arizona: U.S. Geological Survey Scientific Investigations Report 2014-5093, 47 p.

Hardy, T.B., Addley, C., Deacon, J., and Williams, C., 2003, An assessment of potential limiting factors of native fish species in the Virgin River between Pah Tempe and the Washington Fields Diversion: Draft report prepared for Virgin River Resource Management and Recovery Program: Institute for Natural Systems Engineering, Utah Water Research Laboratory, Utah State University, Logan, Utah, $79 \mathrm{p}$.

Miller, M.P., and Brasher, A.M.D., 2011, Differences in macroinvertebrate community structure in streams and rivers with different hydrologic regimes in the semi-arid Colorado Plateau: River Systems, v. 19, p. 225-238.

Rantz, S.E., 1982, Measurement and computation of streamflow: Volume 1. Measurement of stage and discharge: U.S. Geological Survey Water-Supply Paper 2175, 284 p.

U.S. Fish and Wildlife Service, 1994, Virgin River fishes recovery plan: Salt Lake City, Utah, 45 p.

U.S. Geological Survey, variously dated, National field manual for the collection of water-quality data: U.S. Geological Survey Techniques of Water-Resources Investigations, book 9, chaps. A1-A9, available online at http://pubs.water.usgs.gov/twri9A. 
Miller and others- Discharge, water quality, and native fish abundance in the Virgin River, Utah, Nevada, and Arizona, in support of Pah Tempe Springs discharge remediation efforts-Open-File Report 2014-1104 